(Draft of an article published in the Transactions of the Historic Society of Lancashire and Cheshire, 2014, Vol. 163, pages 111-125.)

\title{
Dreams of helicopter travel in the 1950s and Liverpool's undeveloped plans for a city centre heliport ${ }^{1}$
}

\author{
Martin Dodge, Department of Geography, University of Manchester \\ Richard Brook, Manchester School of Architecture
}

\section{The helicopter and the city}

'[The] concept for a high-speed personal helicopter was an early expression of what would become in the years immediately after World War Two an extremely popular vision of the future. To many observers, the helicopter seemed to promise wings for the city dwellers who might land atop their apartments or office buildings. Unfortunately, helicopters were - and remain - difficult to fly, relatively unsafe, noisy, and energy inefficient. ${ }^{2}$

This paper considers a time in the middle of the twentieth century when the helicopter was new and thoroughly exciting form of flying that held great promise to revolutionise urban transportation. The focus is on the development of plans to accommodate passenger helicopters effectively into British cities and, in the context of London and especially Liverpool, how industry experts, property developers, architects and politicians worked to plan new heliport facilities in city centres during the 1950s.

Of course, the notion of vertical flight via a rapidly rotating wing is an old one, perhaps in the minds of ancient Greek philosophers and dating back at least to Leonardo da Vinci in the fifteenth century with his now widely known and intriguing sketch of a prototypical helicopter. Practical development had to wait, however, until the late 1930s when sufficiently light and powerful piston engines were available and allowed aircraft designers to go beyond autogyro planes to true helicopters, capable of vertical lift and forward flight, using the rotor blades alone. Despite more than half a century of 
subsequent technical adaptation and cultural assimilation the helicopter remains a distinctive flying vehicle capable of eliciting response when seen in the skies. The sight - and sound - of a helicopter hovering low overhead still stops people in their tracks.

Whilst the practical application of the helicopter today is undoubtedly limited, the capacity to fly straight up and manoeuvre freely in the air remains deeply appealing to ground dwelling and gravity bound humans. Elemental to the fascination of the helicopter is that it seems to promise direct point-to-point personal flight. Such aerial travel was first shown in popular 1930s science fiction films, such as Things to Come (1936), and was enrolled by Aldus Huxley in his prophetic 1932 novel Brave New World, where personal helicopters are owned by the elite to enable their movement above the social masses. More broadly in the heady days of the American consumer boom and the 'infinite future' of post Second World War suburbanisation some prophesised that helicopters, like the automobile, would come to find a place in every garage. Indeed, the two may well fuse together into a personal heli-cars enabling the successfully businessman to fly from his home in the country to the city office. Such conceptions resonate with desire for population dispersal from certain urbanists and even the disappearance of the cities, for example in ideas developed by visionary architect Frank Lloyd Wright in Broadacre City ${ }^{3}$. While architect Ralph Rapson is well known for having included personal helicopters into several of his sketch designs for prototype houses, perhaps most famously in his drawing for Case Study House No. 4, the Greenbelt House (1945). In 1954 Paul Laszlo’s architectural proposals for an underground city, Atomville, also proposed personal transportation by helicopter or 'convertiplane' (which could be used for land and air travel) and each dwelling would have its own 'flyport' on the surface 4 .

Within the city, it was envisaged that new heliports would provide safe landing and logistical support for mass helicopter activities. There were, however, planning and architectural design challenges for inserting larger heliports effectively into complex and multi-functional urban landscape. ${ }^{5}$ While airports were being located on the edge of cities, at a distance from most of the population and in space open to the skies, heliports needed to be centrally located to exploit the point-to-point rapidity of vertical flight. This logic of location made the size of any proposed site for a heliport hard to justify in commercial terms on landing fees alone, it was also bound up in the difficulty of 
ensuring the pad had an unobstructed approach. The presence of a heliport in a populated area was also associated with concerns about noise disturbance and perceptions of operational safety for what was a 'specialised' machine in the eyes of the public.

\section{The post-war promise of routine helicopter travel}

After the Second World War the helicopter quite rapidly emerged from being an experimental machine that was often dangerous to attempt to fly, to a more safe and airworthy mode of transport. By the 1950s various models of helicopter were being commercially produced and they emerged as one of key icons of post-war futurism, promising the imminent reality of mass inter-city flight and all of the attendant utopian possibilities. As they became reliable and capable, advocates began to plan services and schedules that they could best undertake.

Throughout the 1950s and early 1960s plans were advanced in many British cities for centrally located heliports required to bring the new flying craft safely into the heart of commercial districts, and the appeal of rooftop landing pads was readily apparent in a significant number of proposals. As one MP noted in a 1953 Parliamentary debate on the need to provide heliports:

'I believe that we are on the threshold of a helicopter age in Britain for internal passenger transport. ... The point that I wish to emphasise is that only by the erection of elevated stations in the centre of our principal cities can we gain the maximum benefit from all the time-saving potentialities of these brilliant little machines. ${ }^{6}$

Thinking about how best to handle helicopter landing sites in the post-war period followed several decades of speculation regarding how aviation could best be accommodated in built up areas. Architects, engineers and planners had previously examined ways in which the emergence of large scale aeromobility, firstly by dirigibles and then propeller planes, could be integrated into the fabric of cities as an effective mode of transport for both local trips and long distance travel. As such, rooftop heliport designs of the 1950s period are reminiscent of earlier ideas to utilise skyscrapers to 
tether and transport passengers onto giant airships of the 1920s. They also relate to fanciful and fantastical schemes for elevated runways between towers and large landing platforms built above open spaces such as parks and rivers ${ }^{7}$. One of the most spectacular concepts was developed by municipal engineer Charles Frobisher who proposed huge rotating steel decks high above the city for handling planes ${ }^{8}$, including siting one in the centre of Liverpool (Figure 1).

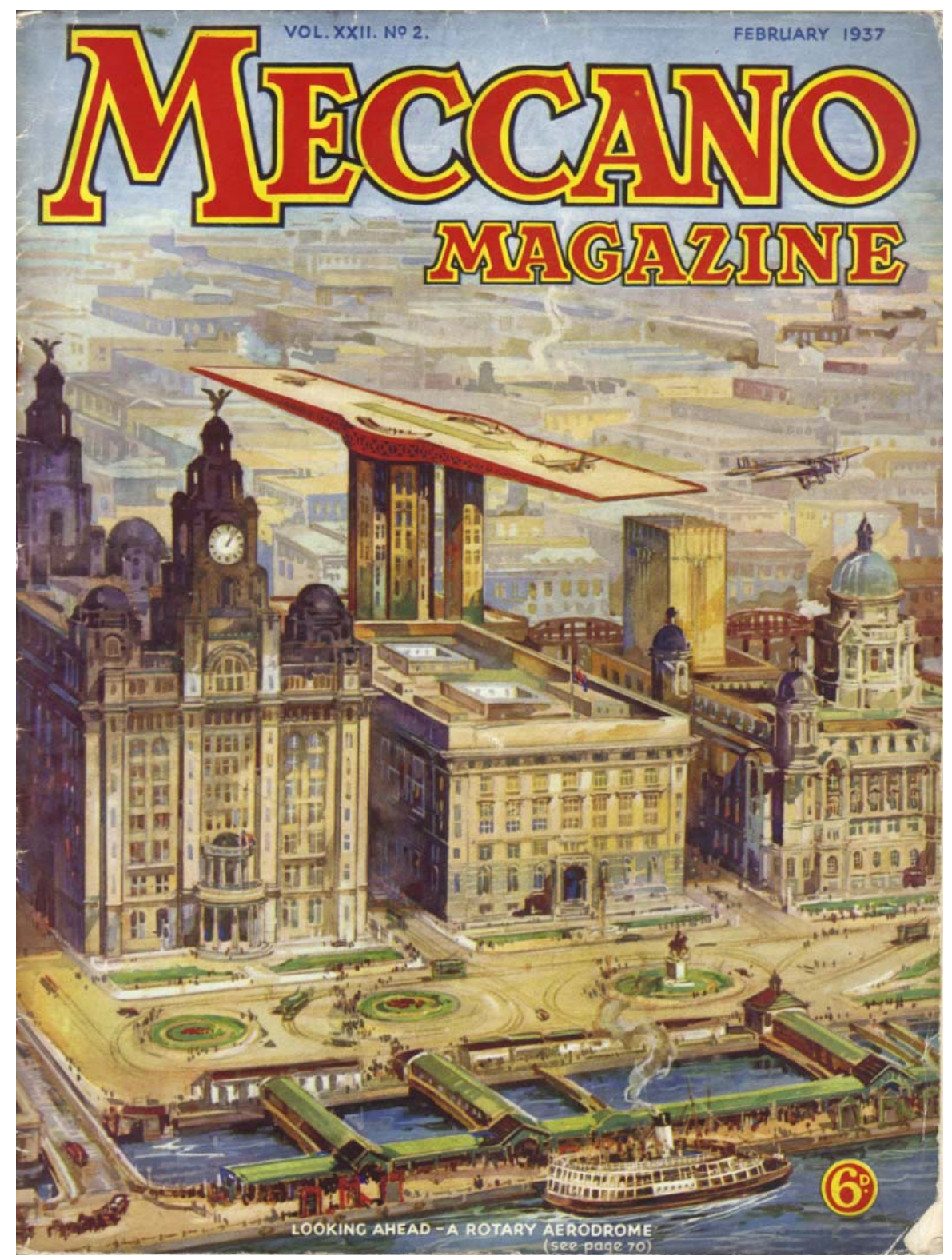

Figure 1. Frobisher's concept of an elevated rotary airport as illustrated on the cover of a 1930s children's magazine. (Source: Meccano Magazine, February 1937. Available from http://archive.org/details/meccano-magazine-1937-02.) 
Unsurprisingly, much of the interest in heliports was focused on central London, as the place with greatest demand for new helicopter services. Through the 1950s multiple schemes were proposed and promoted for heliports in wide array of locations across the centre of the capital. To date we have noted at least fifteen different proposed sites with variously ambitious and developed schemes. Amongst them were ideas to add heli-pads and support facilities to the roofs of mainline rail stations, the construction of landing platforms upon various Thames bridges and similar provision on top of proposed wholesale market buildings. This forward looking activity was partly in response to missives issued by the Ministry of Civil Transport to city authorities to prepare sites for helicopter services ${ }^{9}$. An official report of the Interdepartmental Helicopter Committee from 1951 concluded that 'operation between the centres of towns and cities is essential and feasible. Operated in this way, the helicopter will offer a high degree of public convenience and time saving advantages over all other forms of transport for distances between 50 and 300 miles. ${ }^{10}$ While in a commentary in the Manchester Guardian in 1951 on the potential for regular helicopter flights between major British cities, the correspondent noted that:

'...the convenience and economy of any such service will call for a city landing ground almost as centrally sited as the main railway stations. News that the siting of a Manchester helicopter station is shortly to be discussed with the specialists of the BEA [British European Airways] ... gives further assurance that an appropriate space is likely to be earmarked against the needs of a new service from which the city could hardly be excluded. ${ }^{11}$

Of the more elaborate proposals advanced in the early 1950s one was for a huge 'helidrome' to be built on stilts above Charing Cross train station ${ }^{12}$ (Figure 2), another concerned heliport provision in relation to the large-scale development of the South Bank site after the closure of the Festival of Britain ${ }^{13}$. This proposal seems to have dropped in favour of another rooftop heliport solution on top of Waterloo train station, although this was seen as more problematic as it was further from the river and situated in a more densely built-up area ${ }^{14}$. Nearly a decade later architect Charles Glover advanced a scheme to relocate the wholesale market from Covent Garden to a new building above the railway sidings north of Kings Cross, which 
would have included a rooftop heliport ${ }^{15}$. All these schemes were never developed beyond the drawing board stage, and whilst inspirational and often alluring to some, they appear quite fanciful in a contemporary context. Whether or not Waterloo, New Covent Garden Market or Charing Cross were realistic or could have been realised as operational heliports may only truly be ascertained by further scrutiny. In some senses they were architectural dreams in a similar mould to the early 1930s schemes for landing strips for propeller aeroplanes in the middle of London ${ }^{16}$.
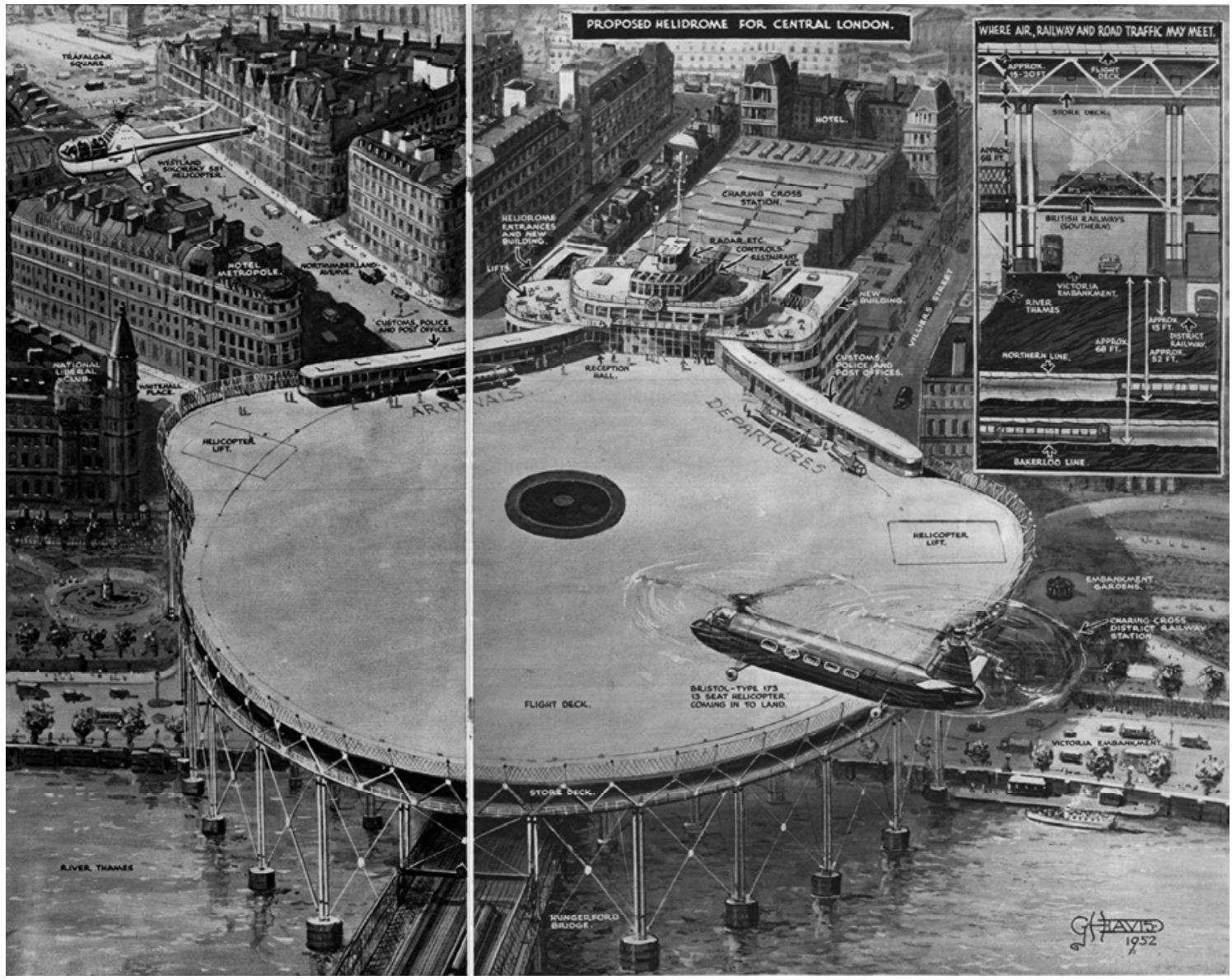

Figure 2. Publicity drawing of a speculative proposal for a helidrome to be built over Charing Cross train station. It would have comprised a $90 \mathrm{~m}$ amour plated concrete pad elevated about $30 \mathrm{~m}$ above the existing train shed and extending out across surrounding roads and ground structures. Below the main landing deck was to be a secondary level for helicopter storage and maintenance. The helidrome's positioning supposedly would have allowed for safe, unobstructed approach along the Thames. (Source: Extract from Illustrated London News, 2 February, 1953, pages 170-71. Scanned copy courtesy of John Weedy, <www.iln.org.uk>.) 
More serious consideration of the need for and the siting of a heliport in central London were undertaken by an official Ministry of Aviation expert panel in the late 1950s. They presented their findings in 1961 in a substantial report, with much supporting data and detailed mapping, and their underlying thinking was summarised as follows:

'Since the helicopter's appeal depends on saving time, the heliport should be brought as close as possible to the main source and destination of a substantial proportion of the traffic....it should not be much more than a quarter of an hour from Grosvenor Sq, and ideally, between the West End and the City. ${ }^{17}$

In their deliberations, the Committee on the Planning of Helicopter Stations in the London Area had formally evaluated nine different sites capable of handling routine helicopter services and they selected three as the most viable: Nine Elms goods yard, Cannon Street Station and St. Katharine Docks. Each of these sites had a riverside aspect, as the Thames was seen to offer a safe flight corridor over the water. None of the proposed sites in the 1961 Report were developed as a helicopter station. (In the end a supposedly temporary helipad was erected at Battersea by the Westland company as a cantilevered platform out over the River Thames. It opened to helicopter traffic in April 1959 and remains in operation ${ }^{18}$.) The 1961 Committee report was probably the zenith for serious central governmental discussion on the need for large city-centre heliports and the idea of wide-scale use of helicopters for civil transport began to recede from then onwards.

\section{Taking steps toward inter-city passenger helicopter services}

By end of the 1950s the major concern was not so much the physical architecture and siting of heliports but the need to develop an economic model that would make regular passenger helicopter services profitable for operators. While there was hope of putting together a plausible looking network of scheduled inter-city flights in the UK at the start of the 1950s (Figure 3), the financial situation proved more difficult due to the small size and relative inefficiency of helicopters available at the time. Yet, there was considerable anticipation for development of much larger twin-engine helicopters which 
would allow for, arguably, safer operations over built up areas and, crucially, have sufficient load carrying capacity to lower the per passenger mile costs. In 1952 BEA's chief executive stated their key requirement for commercially viable services was for 'a large multi-engined helicopter capable of cruising at not less than $150 \mathrm{mph}$ and offering between $40-70$ passenger seats by $1960 .^{, 19}$

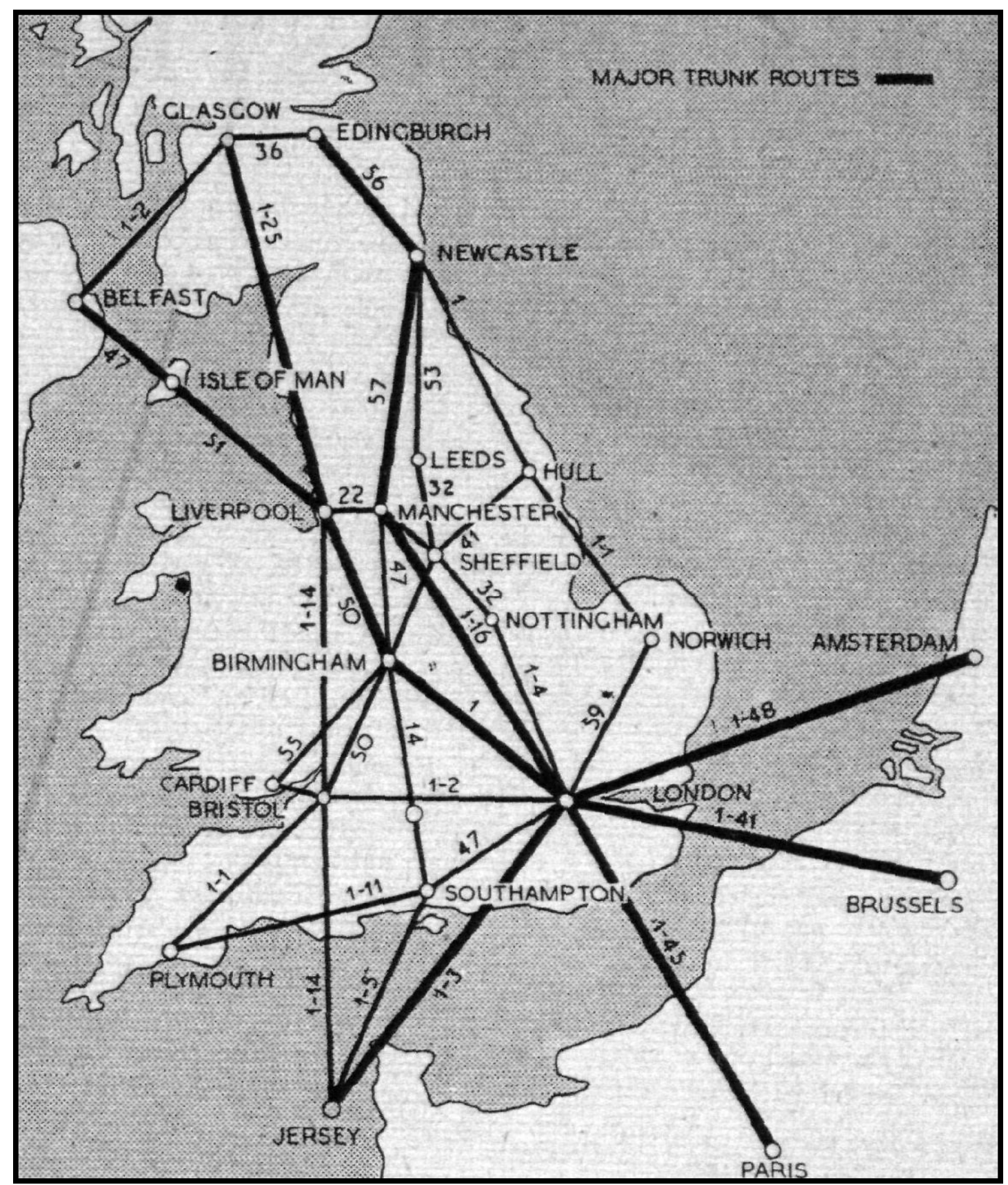

Figure 3. A tentative network of inter-city helicopter services proposed in 1952, premised on larger aircraft capable of carrying 48 passengers that were expected to be available by the end of the decade. The numbers on the route lines indicate journey times based on the helicopter flying at $160 \mathrm{mph}$. (Source: Anon., "The commercial future of helicopters”, Flight Magazine, 14 November 1952, p. 622.) 
Beginning in 1950 BEA undertook several long distance trial services for paying passengers. The ambition was to see how helicopters could become more than personal air taxis, replacing private motorcars for ad-hoc journeys and to develop scheduled services, like "buses of the skies". The first experiment began in June 1950, with a daily service between Liverpool and Cardiff, plus a request stop at Wrexham to collect any passengers that wished to join ${ }^{20}$. The route ran in a fairly straight-line from Speke Airport, over Chester, across mid Wales and past Abergavenny into Pengam Moors Aerodrome on the eastern side of Cardiff. (Figure 4) The 130 mile journey took around 1 hour and 40 minutes with the helicopters cruising at a speed of $85 \mathrm{mph}$ and altitude of around 1,500 feet $(457 \mathrm{~m})$. Flights departed from Liverpool at 9.00am and from Cardiff at 9.45am, with a return journey in the late afternoon (the timings were arranged so helicopter passengers could connect at Speke to aeroplane flights to Belfast, Dublin and the Isle of Man). ${ }^{21}$ Fares were charged at $£ 510$ s return or $£ 310$ s single. It was acknowledged in the media at the time as the world's first scheduled helicopter service and Chairman Kenneth Davies of the Welsh Advisory Council for Civil Aviation asserted that 'Wales might have languished in the past, but this will put her on the world map of aviation. ${ }^{22}$ This novel mode of transportation held the promise to overcome the geographical constraints of the principality, especially the fundamental disconnect of the northern and southern populated zones and the lack of a fast rail or road route across the rugged terrain in-between. While the first passenger helicopter flights across Wales were encouraged by local politicians, the service was not commercially viable and the small helicopter employed (the Sikorsky S.51 model) could only carry three passengers and their luggage. The Liverpool to Cardiff service operated for just under a year, and was used by only 819 passengers ${ }^{23}$.

There were further experiments in scheduled helicopter services during the early 1950s and the second trial was a more obvious choice, flying between the two major centres of population in Britain. BEA commenced a service linking Birmingham and London in June 1951. Again this was an airport-to-airport routing and as before the service ran for less than a year. From 1955 to 1956 there was an attempt at a commercial helicopter shuttle service from central London, operating from a vacant plot on the South Bank out to Heathrow Airport. These were all trial services required government subsidies to 
operate and were often under-used. They were also fundamentally ineffective in testing the raison d'etre of the helicopter: that it could take-off from the middle of towns instead of being tied to peripheral airports. Indeed this point was flagged in a short report in 1951 in The Times, when they noted that '[s]ervices to the centres of the cities will not be contemplated until twin-engined helicopters are available ${ }^{24}$. The small single engine helicopters of the early 1950s were deemed to be unsafe for routine operation over built up areas as mechanical failure could have resulted in a serious crash. From the reporting of the BEA trial services it would appear that their aim was to evaluate the machines, test flight systems (radio beacons, autopilots, ATC), develop pilot skills and they were not really about building a robust business case for routine inter-city helicopter transportation.

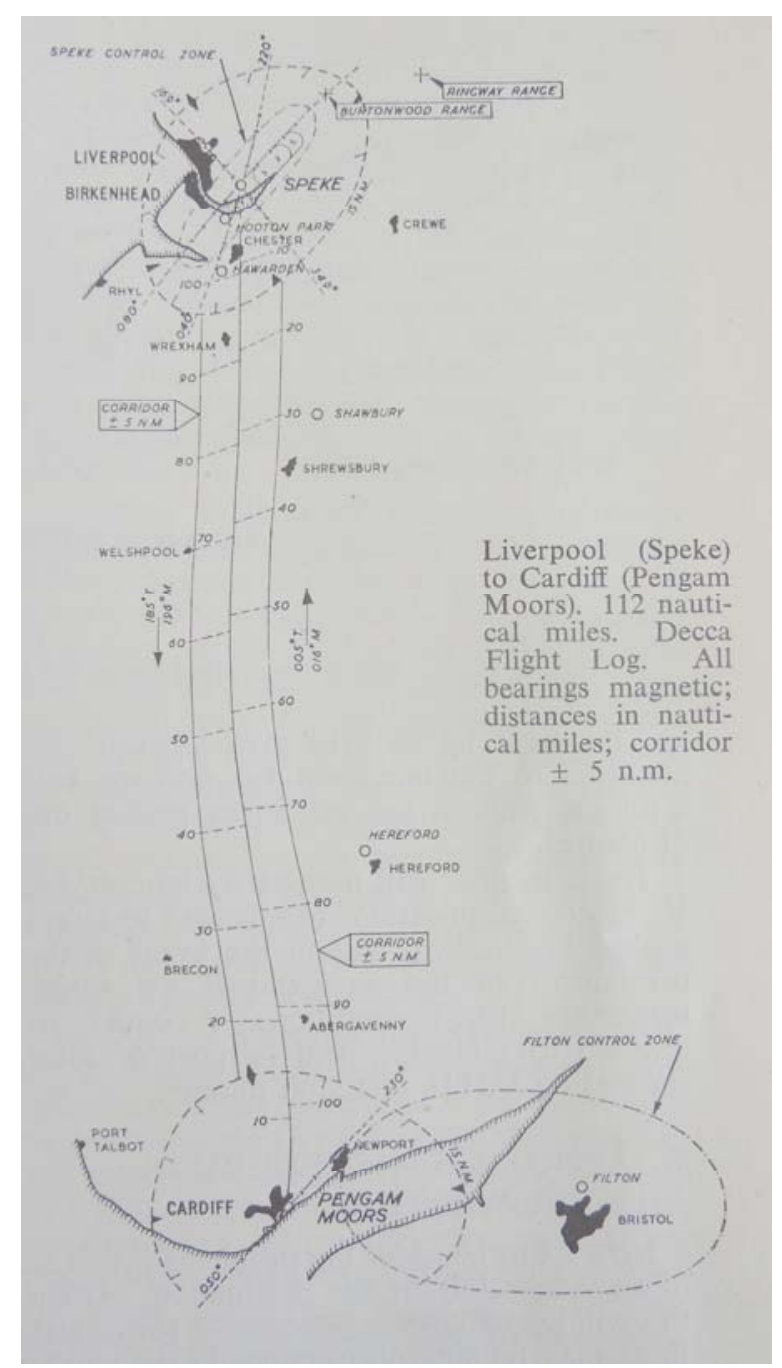

Figure 4. The flight path of the Liverpool - Cardiff helicopter service operated by BEA from June 1950 to March 1951. (Source: R.H. Whitby, "Some operational problems of public transport helicopters", Journal of the Royal Aeronautical Society, 56, January 1951, p. 29.) 


\section{Liverpool plans for city centre heliport}

'The landing station should not be complicated and expensive otherwise the helicopter, with its unique ability to drop from the sky into a small space, will loose one of its advantages. The passengers should experience no more formalities that they encounter at a railway station. ${ }^{25}$

The ending of the BEA helicopter service from Speke Airport in spring 1951 did not seem to preclude continuing interest in Liverpool for the possibilities of this mode of transport. Through the next decade Liverpool seems to have been one of the leading municipalities in England planning for a centrally located heliport, evident in part through the public activities of its City Engineer and Surveyor Henry T. Hough ${ }^{26}$. In the summer of 1953 there was an experimental visit of a helicopter to the city with the aircraft landing in the centre on a temporary car park on Paradise Street. (This neighbourhood had much cleared ground resulting from Second World War bomb damage. ${ }^{27}$ ) The presence of the helicopter evidently attracted quite a crowd of curious onlookers to witness the event and press photographs captured the obligatory handshakes between passengers and local dignitaries (Figure 5). The presence of the helicopter at this place was prescient in some respects because the site, formerly warehousing, and conveniently positioned between docks and the civic centre of Liverpool would feature in late 1950s as the possible location for a permanent heliport for the city.

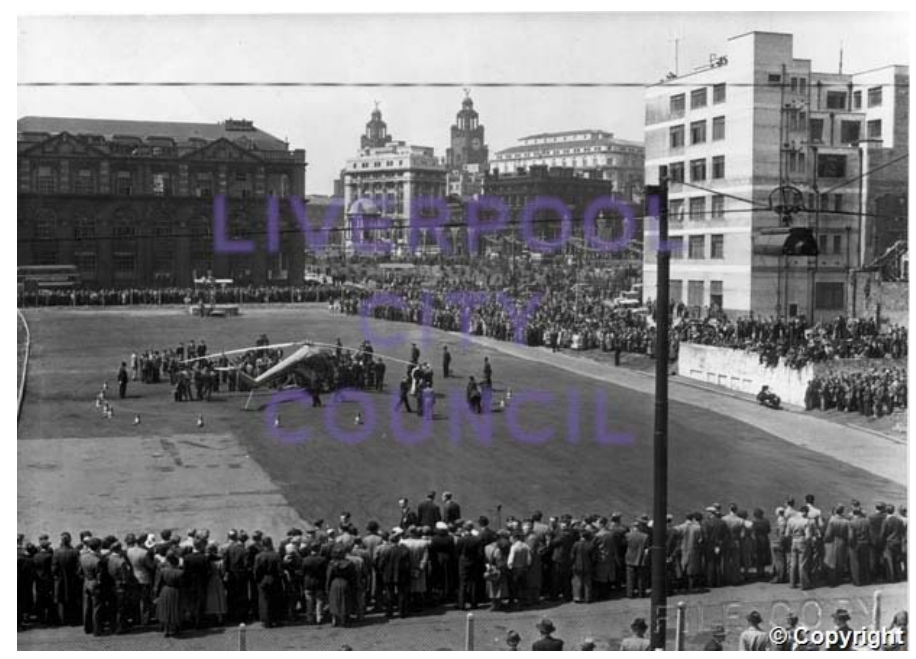

Figure 5. The visit of a Bristol 171 helicopter to Liverpool in June 1953. (Source: Liverpool Record Office, ref. 352 ENG/2/12837.) 
Henry Hough invested a significant amount of time in advancing the helicopter agenda within a municipal context and in particular he focused on the pragmatics of facility design and finding suitable sites. As he recounted in 1954, 'During the past few years I and members of my staff have made careful investigation into the landing station requirements of helicopters in conjunction with development engineers of BEA and of aircraft companies. ${ }^{28}$ Hough and the Chairman of the Post-War Redevelopment Committee conducted a study visit to the USA in 1953, which included a helicopter flight into New York City landing pad on the roof of the Port Authority's 16 storey headquarters. He regarded the most relevant role of the helicopter in a civilian transport context as performing the role of the bus, and being able to fly above congested city streets; 'There should be no tendency for a helicopter station to be compared with an airport. One of the chief advantages of the helicopter is that like a bus it can stop anywhere there are simple landing facilities. ${ }^{29}$

As evidenced by wide reporting of his ideas in the technical press, Hough was influential in the 1950s in the translating the policy statements coming from the Ministry of Aviation and the growing experience of the helicopter industry into more formalised planning advice for municipalities. In November 1954 he gave a high profile public lecture at the Royal Aeronautical Society in London on the 'Design of Helicopter Operating Sites' in which he carefully delineated the physical requirements of the heliport and some of the wider town planning issues relating to site selection (such as safe clearances and noise disturbance $)^{30}$. The lecture included a number of plan drawings for the layout of an idealised ground level and rooftop heliports (Figure 6), and these influenced designs proposed by other municipal authorities, including Manchester and Glasgow. He stated that ' $[\mathrm{t}]$ he only apparent disadvantage of the roof station was that the extra cost of providing and supporting a sufficiently strong roof slab ... However, it was felt that the extra cost would probably be no more ... than the cost of sterilizing, either wholly or partly, much valuable land in the climb planes of the ground-level station ${ }^{31}$. The lecture also touched upon the possible siting of helicopter landing decks on floating pontoons, which was particularly relevant in the context of Liverpool's situation with the close access from the city centre to the Mersey estuary, although it was dismissed on safety grounds given the volume of shipping traffic associated with the docks and ferries. 
Reports and some surviving plans show that Hough and his colleagues in the Corporation were considering several other possible locations for a heliport:

'Liverpool has in mind several surface landing sites in its long term plan, and in addition it has approved in principle a roof-top landing site over a bus station and multi-storey car park in the City centre itself where, due to war damage, land is already available for its erection between Paradise Street and South John street. ${ }^{32}$

Other heliport sites evaluated included one located off Wavertree Road. On inspection this location seems inappropriate as the noise disturbance would have likely impacted on the amenity of the adjacent Botanic Gardens; it would also have been some distance from the city centre ${ }^{33}$. Another possible solution considered involved covering over the redundant Duke's Dock, located on the waterfront next to Albert Dock, it afforded the benefits of open approaches for helicopters over the Mersey and thus minimised noise disturbance $^{34}$. (Figure 7) The fact that multiple sites were considered does indicate serious interest in Liverpool for developing a permanent heliport but also some uncertainty over how and where the new mode of transport should be inserted into the existing urban landscape. Such uncertainty in the process of site selection for a new technology appears as a pattern in municipal decision making around the helicopter and was replicated in Manchester in the mid $1950 \mathrm{~s}^{35}$. 


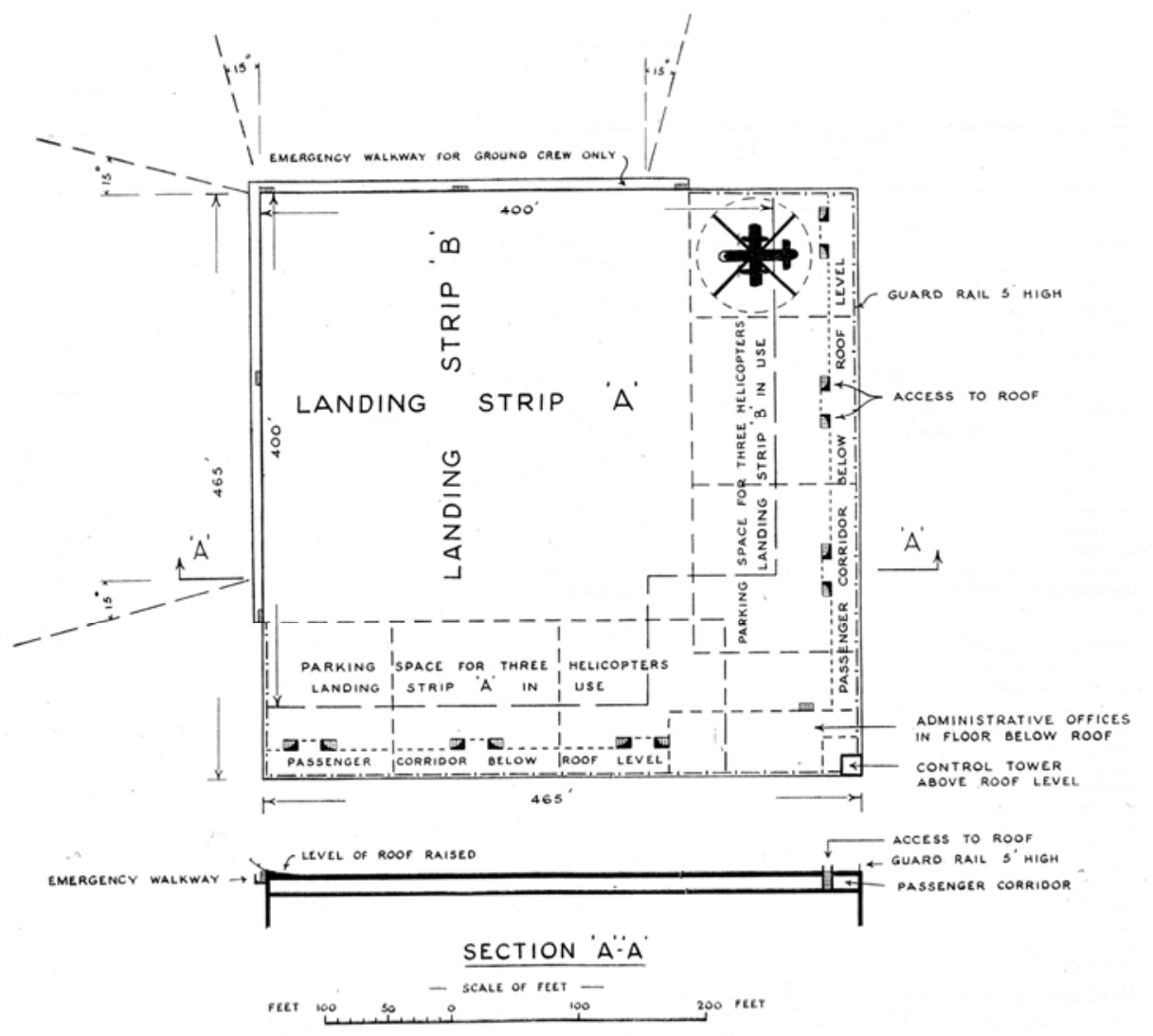

Figure 6. Hypothetical layout of a rooftop heliport. It was one of plans included in Hough's 1955 lecture. (Source: H.T. Hough, “The design of helicopter operating sites for passenger services", The Surveyor and Municipal and County Engineer, 24 December 1955, p. 1252.)

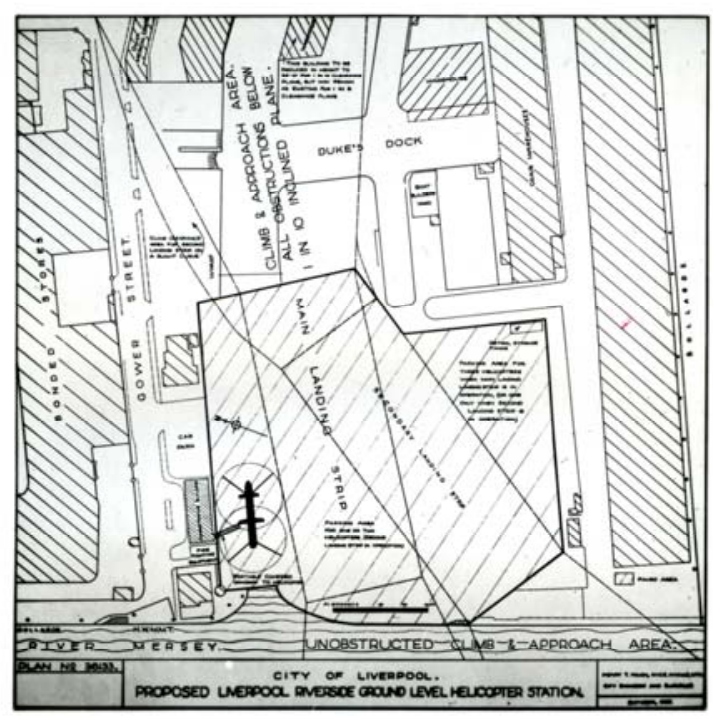

Figure 7. Duke's Dock plan for a ground level heliport, Henry Hough, City Engineer and Surveyor, 1955 (Source: Liverpool Record Office, ref. 352 ENG/2/15588.) 
For Liverpool City Corporation the most developed concept seems to have been the boldest, one of putting the heliport on top of the new bus station / multi-storey car park that was proposed for the bomb damaged area of the city centre between Paradise Street and Canning Place. (Figure 8) This scheme was reported in the press in the 1950s and surviving drawings from the City Engineers Department, now held by the Liverpool Record Office, shed some light on the design of this structure, even though it was never realised in accord with these plans. The structure was conceived as a major new transport facility and the centrepiece of Reconstruction Area One; it would have been a sizeable building covering several blocks and necessitating the reconfiguration of several local streets. An undated perspective drawing shows the substantial volume situated amidst a number of new buildings. (Figure 9) The expansive flat roof is shown in active service with three helicopters in place, including twin rotor passenger craft that were anticipated to be the mainstay of any aerial bus-style service. The front of building with main entrance and offices is located on Canning Place, which is drawn as a twinlane boulevard with central traffic divide. To the rear of the new car park can be seen the Coronation Gardens and Telegram House on Thomas Street, one of the few buildings in the vicinity that survived the Blitz of 1941.

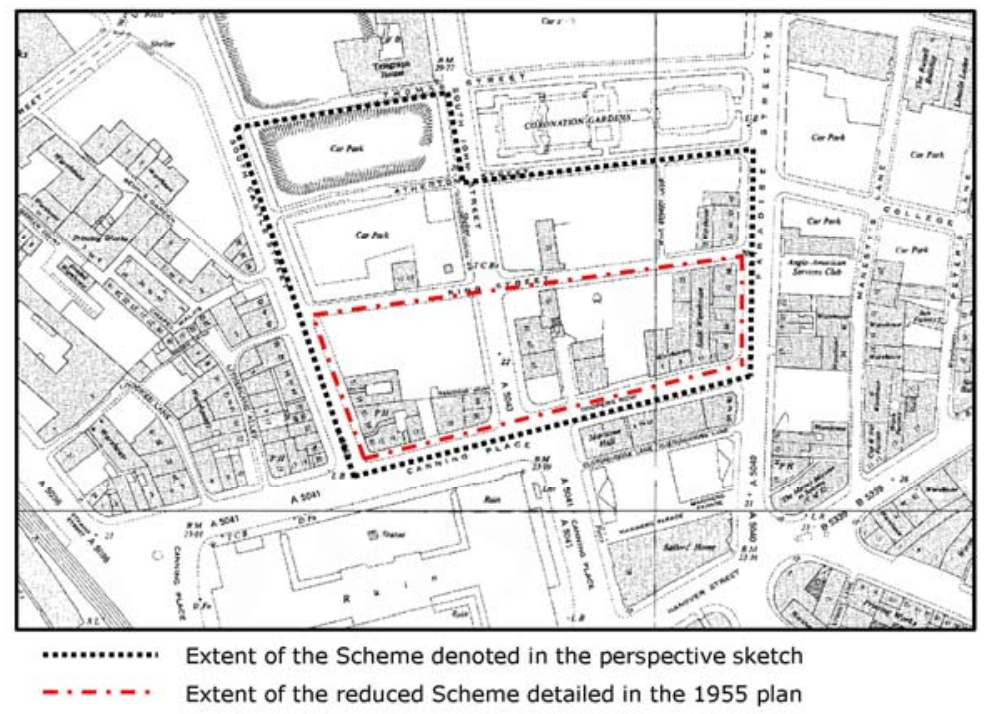

Figure 8. Delineating the locale and extent of the Paradise Street bus station / car park which was initially proposed to include a rooftop heliport. The spatial extents of two different design options are delineated by the hatched outlines. (Source: authors map.) 


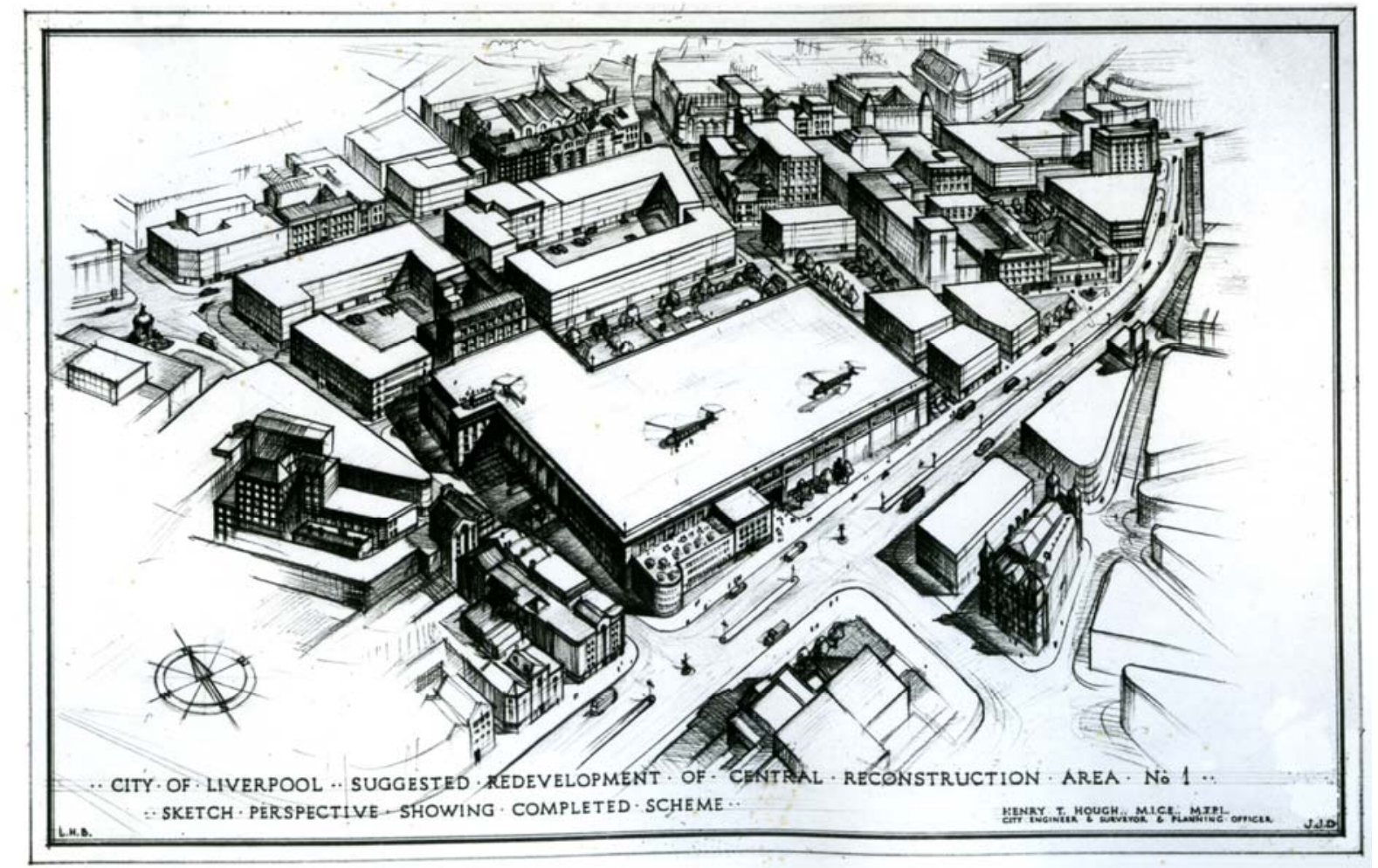

Figure 9. Architectural sketch of the Paradise Street bus station / car park.

Undated but likely drawn in the early 1950s. For orientation, in the immediate foreground is the ruin site of the Custom House and the detailed building shown bottom right is the Sailors' Home; top left of the scene is Derby Square with its distinctive memorial to Queen Victoria. (Source: Liverpool Record Office, ref. 352 ENG/2/12031.)

The outline proposal shown in the perspective sketch was superseded as the scheme was specified in more detail. In particular the scale was significantly reduced, possibly due to reconstruction ambitions being curtailed to fit the realism of available budgets. Figure 10 shows the proposals for the Paradise Street transport hub in 1955, approximately half the size of the earlier sketch with the main vehicular entrance relocated to Atherton Street rather than from Canning Place / Cooper Row. While the area of land taken up by the building was reduced overall, the rooftop heliport was more elaborate than initially conceived. The cross section shows the allocation of space for different activities: the large bus station with multiple loading bays on the ground floor, surmounted by two floors of car parking and access ramps, with surrounding areas of offices fronting the street (notes on the drawing indicate that they would be 'protected acoustically'). The double height third storey has an open air platform for passengers to embark to the stationary helicopters and a portion of enclosed storage space / workshops. Two vehicle 
lifts are indicated to raise the loaded helicopters to the upper roof level for taxi, take-off and landing. The intended separation of helicopter activities in this design configuration seems to be quite distinctive and is perhaps indicative of a heightened concern for passenger comfort and safety. The perimeter of the upper landing deck is shown as ringed by 'carrier type guard fence'. In the use of large vehicle lifts and fencing one can clearly see parallels being drawn between the heliport design and the aircraft carrier. (These had supplanted the battleship to become the most decisive weapon of naval operations in the Second World War.) It is interesting to speculate how well the facility, set out in the design in Figure 10, would have operated if it had been built. In many respects it is adheres to the contemporary concept of an integrated transport interchange - all that was missing was a connection to a subway or surface tram system. The ambitious plans for bus station with multi-level heliport on the Strand / Paradise Street site, however, remained unrealised during the 1950s.

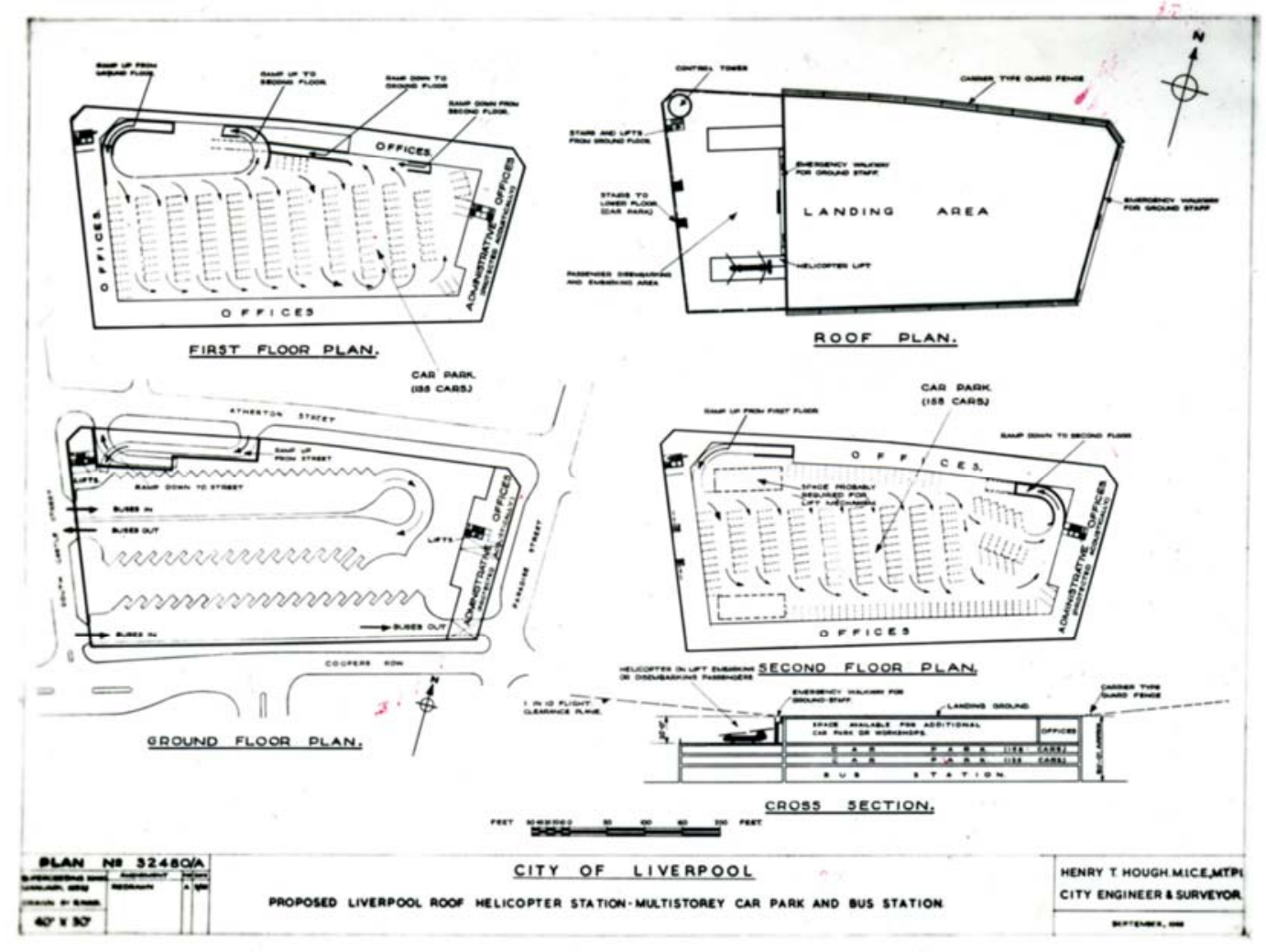

Figure 10. Plan and cross sectional views showing the internal arrangement of facilities in the Paradise Street structure, 1955 (Source: Liverpool Record Office, ref. 352 ENG/2/15587. NB reproduction from poor quality original.) 


\section{In the 1960s in Liverpool}

Despite efforts by Hough and the various possible sites considered, by the end of decade, there was still no heliport in sight. The difficulty of site selection was concisely summarised the City Engineer in 1959:

'In view of the area needed to fulfil the requirements of approach paths free from obstruction and to prevent nuisance to the public, a permanent ground level landing area is virtually impossible in the commercial or shopping centre of a city like Liverpool.' 36

Like many British cities, Liverpool had more pressing needs in terms of housing provision and the construction of new schools that took priority through the 1950s. Furthermore, according to Francis Amos, City Planning Officer, 'because of the obsolescent character of parts of the Merseyside economy, initiative on a grand scale did not materialise from the private sector and was not fostered by the local authority. ${ }^{, 37}$ In the next decade the post-war reconstruction agenda morphed to become one of comprehensive development areas (CDAs), designed to tackle not just war damaged sites, but larger decaying areas, slum housing and the poor quality urban realm. ${ }^{38}$ Legal powers promoted under revisions to the Town and Country Planning Act (1947) afforded municipal authorities the opportunity to package large swathes of land as opportunities for private sector investors. ${ }^{39}$

The Paradise Street area of Liverpool city centre remained underdeveloped in the minds of planners and civic elites and was seen as ripe for large-scale structures. The site was programmed by Graham Shankland's team in their comprehensive Liverpool City Centre Plan of 1965 and received CDA approval in July 1966. The 1965 scheme did not envisage a heliport, but retained a significant amount of vertically layered and large scale buildings. It was identified as the 'Strand - Paradise Street CDA' and was slated for a 'megastructure’ comprising shopping arcade, topped by a triple deck 2,500 space car park and on this roof terrace would be a long six storey slab of maisonettes; the structure would be surmounted by five towers of residential flats (Figure 11). The advantages of this arrangement were asserted: 'By stacking different buildings on top of one another in this way, it will be possible to create space for a new park of some six acres. ${ }^{40}$ In spite of the scale of the scheme there was no space allocated for helicopters 
(or buses for that matter) because by the mid 1960s it was apparent to local authorities that the hoped for helicopter revolution had not materialised. Although they were still cited as possibility, as the 1965 Plan notes:

'Among trends in air travel likely to affect the central area, the most important is inter-city helicopter services. These may be introduced, if quieter engines can be evolved but at present, particularly with the airport being so close to the centre, no heliport is proposed.' 41
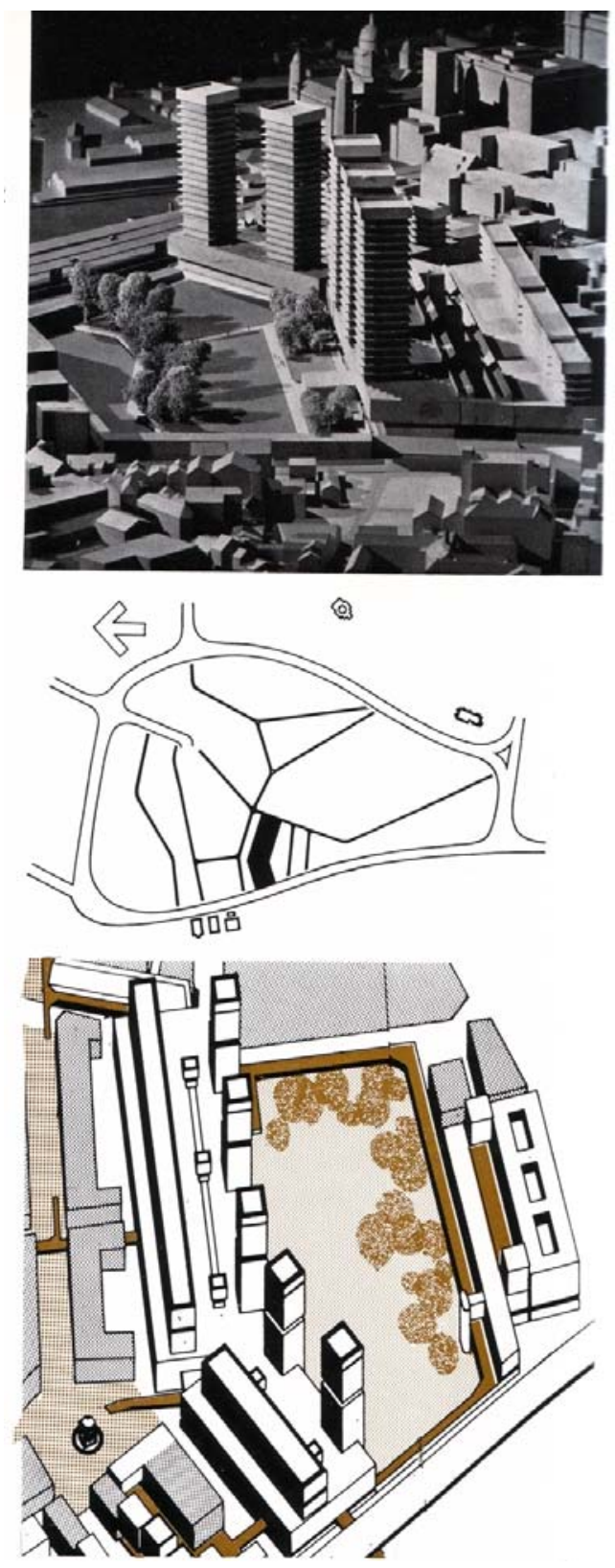

Figure 11. Architects model, location map and block rendering of the 'megastructure' proposed to fill out the Strand - Paradise Street CDA. (Source: Liverpool City Centre Plan, City and County Borough of Liverpool, 1965, p.126.) 
As with many ambitious 1960s projects, conceived in the heady days of urban renewal in the Northern cities, the Strand - Paradise Street scheme was not realised. According to the 1970 review of Shankland's 1965 City Centre Plan the 'multi-level scheme did not prove attractive to developers and so a simpler solution has been devised [with] ... the same elements as were proposed in the original scheme, but disposes them horizontally instead of vertically. ${ }^{42}$ The city authorities in Liverpool did proceed with new bus station and large multi-storey car park in this area in the early 1970s although the ambition of the building was much reduced. (Figure 12) The design of the Paradise Street facility was ultimately largely functional, reflecting the constraints of municipal budgets and the direction of the construction industry towards preformed and unitised building methods. (Figure 13) Clearly this structure made no pretence of serving helicopters - the 1970 Plan Review document makes no mention of them - and it became a mundane, quotidian part of the urban landscape of Liverpool city centre for several decades. Notwithstanding its solid concrete presence, the multi-storey car park became a victim of another round of redevelopment, this time driven by need for highend 'mall style' retail in central Liverpool and the capital resources of private developers, Grosvenor. The bus station closed at the end of 2005 and the whole structure was subsequently demolished.

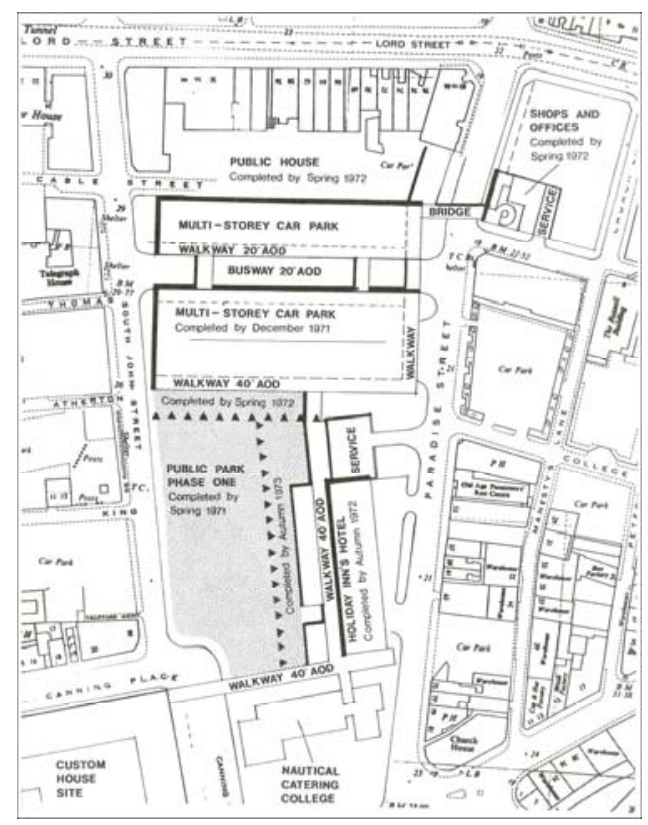

Figure 12. A record of the progress on the car park and bus station on Paradise Street site. (Source: F JC Amos, Revised Planning Policy: Strand St/Paradise St Development, (1972) Liverpool City Planning Department.) 


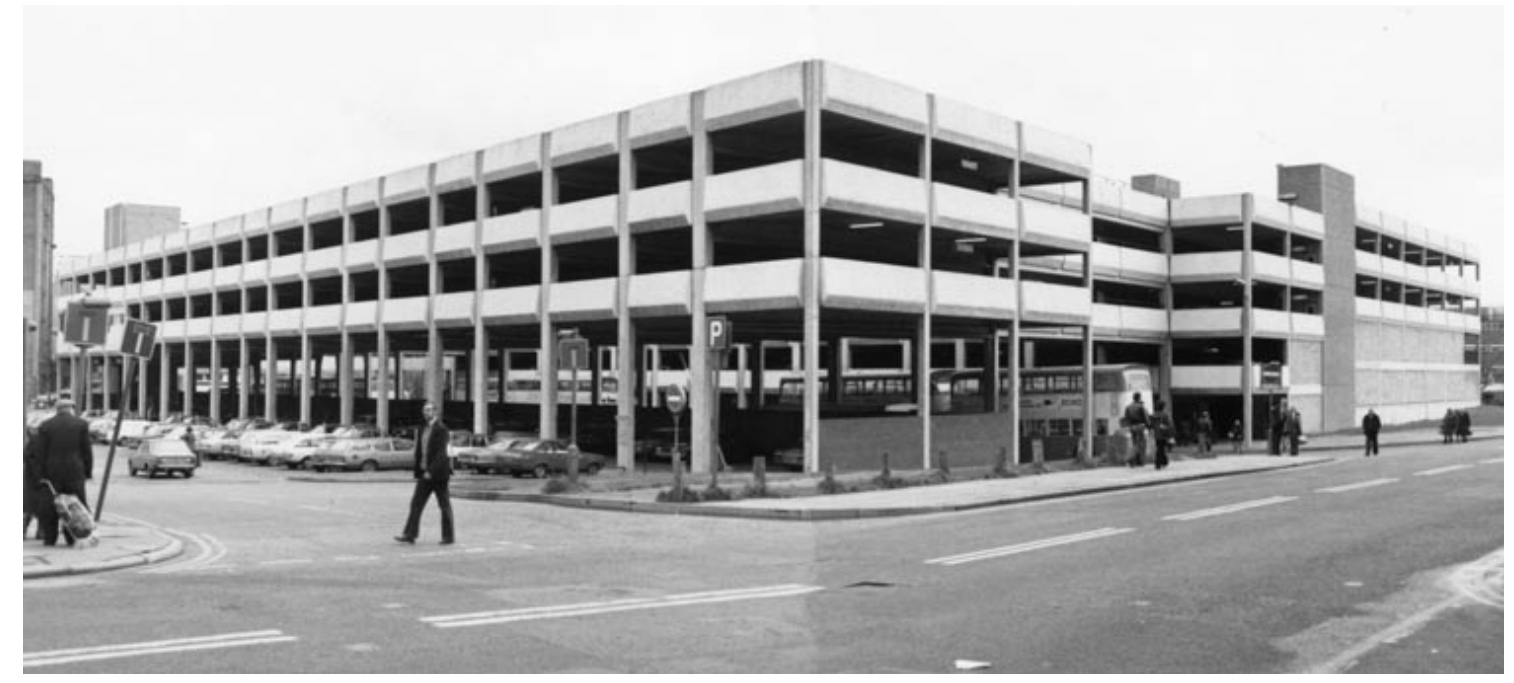

Figure 13. Paradise Street car park / bus station, 1978. Panoramic photograph taken by Stan Roberts. (Source: http://streetsofliverpool.co.uk/how-the-1970schanged-liverpool-3/paradise-street-1978/ )

\section{Conclusion: Why passenger helicopter services did not happen?}

'For my part, I am convinced that the helicopter will be the bird of burden for domestic use in the future. However, I must emphasise the words 'in the future' because I do not believe that this is immediately round the corner. ${ }^{43}$

'All enquiries at any time seemed to lead to the conclusion that the commercial future of the heliport was always about twenty years in the future. They were operable for military or emergency purposes or for purposes with a high element of 'social benefit' but in terms of normally generated traffic for civilian purposes [whether pleasure or business trips] the costs were relatively high and operating precautions ... relatively severe. ${ }^{44}$

The above quotes were made in 1953 and 1966 respectively and both are still applicable today. They present an account for the fact that the vision of routine, mass passenger helicopter use failed to materialise and the potential of vertical flight from city centre heliports has not revolutionised urban travel. The future of inter-city aviation anticipated by many in the post-war period never arrived. 
Nothing came of the schemes for city centre heliports of the 1950s in London, or any of the major provincial centres like Liverpool or Manchester. And by the mid 1960s the realistic prospects faded at a national scale for commercially viable inter-urban helicopter services ${ }^{45}$. As a consequence no major purpose-built city centre heliports have been constructed in any British cities, with the exception of the Battersea landing pad in London. Certainly, there are no spectacular landing decks on skyscrapers, over train stations or even on the roofs of multi-storey car parks.

Why were roofs of high structures in city centres not routinely dotted the ' $H$ ' landing signs? This was due to the lack of demand and financial feasibility of helicopter services, serious issues of noise disturbance along with perceived safety risks. All these detrimental factors were evident in the failure of perhaps the most icon heliport on the top of the sixty storey Pan Am (now MetLife) building in Manhattan. Helicopter flights operated intermittently from 1965 but were not very profitable and were subject to strong complaints about noise $\mathrm{e}^{46}$. The landing deck finally closed following a serious accident involving a helicopter in May 1977 that killed five people. The publicity around this incident put paid to rooftop heliports in most Western cities. Security concerns around low-level flying over cities has been significantly heightened since the terrorist attacks of September 11, and in the last year or so serious question marks have again been raised about risks of helicopter operations following two high profile accidents over British cities (spectacular crash in Vauxhall, London in January 2013 that killed two and the incident in central Glasgow in November 2013 when a police helicopter crashed into a crowded pub leaving ten dead).

The promise to be able to rise above congested city streets still remains an appealing prospect, with the helicopter's superiority over fix-winged aircraft is its ability to take off and land vertically in a relatively small space and thereby offer the flexibility of point-to-point journeys. In contemporary British cities, however, the role for helicopters remains marginal. The only point for regular commercial helicopter operations in centre of London remains the Battersea landing pad and for Liverpool the nearest operating area it is at John Lennon Airport. This kind of provision only support helicopter traffic for a small number of elite travellers, pilot enthusiasts, pleasure trip 'experiences' and, of course, the emergency services. Indeed, the most visible presence of helicopters in Britain is the police air support units hovering over city centres and the occasional Air 
Ambulance service ferrying critical patients to hospitals. As such the sound and sight of helicopters in the skies above the city still attracts attention as it indicates potential trouble and trauma in the streets below.

Yet the past does not determine future. The situation might change, in the case of Liverpool if plans for the wholesale - and controversial - regeneration of the waterfront come to pass. Passenger helicopters might then make a regular appearance in the city centre using a helipad on one of towers in the Liverpool Waters mega-development. Although such a landing facility would be for elite occupants with the helicopter serving as the ultimate taxi for the very wealthy.

\footnotetext{
${ }^{1}$ This article is derived in part from: R. Brook and M. Dodge, Infra_MANC: Post-war Infrastructures of Manchester (Bauprint: Manchester, 2012), and a presentation M. Dodge, "Planning for heliports: forgotten ambitions for urban space and movement”, Infrastructure and the Rebuilt Post-War City Workshop, 25 March 2013, Birmingham.

2 J.J. Corn and B. Horrigan, Yesterday's Tomorrow's: Past Visions of the American Future (Baltimore, MD: The Johns Hopkins University Press, 1984), p. 100.

${ }^{3}$ F. Lloyd Wright, The Disappearing City (New York: William Farquhar Payson, 1932). Cf. “The romantic illusion” in H. Pearman, Airports: A Century of Architecture (London: Lawrence King, 2004)

${ }^{4}$ C. Kerr, “At Home, 2004 A.D.”, Popular Mechanics, October 1954, pp. 153-256.

${ }^{5}$ The helicopter seems to receive little coverage in the planning literature; although see: Branch, M.C. 1964, "Urban Planning and the New Mobility", Journal of the American Institute of Planners, 30(1): 2-9; Ferguson, E. 1992, “Up, up, and away”, Planning, 58(2): 10-13; Finch, H.P. 1966, "Heliports in urban areas” Institution of Civil Engineers Proceedings, 33(1): 53-63.

${ }^{6}$ Mr Gerald Nabarro, MP for Kidderminster, House of Commons debate on 'Helicopter station, London', 2 February 1953 [Hansard, HC Debate, 2 February 1953 vol. 510 cc1615-26], $<$ http://hansard.millbanksystems.com/commons/1953/feb/02/helicopter-station-london>.

${ }^{7}$ See R. Bruegmann, “Airport city”, in J. Zukowsky (ed.), Building for Air Travel (Munich: Prestel, 1996), pp. 27-50.

${ }^{8}$ He developed the idea sufficiently for it to be patented in July 1934 as "Improvements in and relating to elevated centrally pivoted rotating aerodromes or airport landing grounds” (Ref. GB413773a).

${ }^{9}$ See House of Commons debate on "Helicopter station, London”, 2 February 1953 [Hansard, HC Debate 2 February 1953 vol. 510 cc1615-26],

<http://hansard.millbanksystems.com/commons/1953/feb/02/helicopter-station-london>.

${ }^{10}$ Ministry of Civil Aviation, First Report of the Interdepartmental Helicopter Committee, September 1950, M.C.A.P.92 (HMSO: London, 1951), p. 13.

11 “A helicopter station”, Manchester Guardian, 11 July 1951, p. 6.
} 
${ }^{12}$ The scheme was initially advanced by MP Norman Dodds in May 1951 based on design work by the architects Aslan and Freeman [cf. "London rotor-station design”, Flight Magazine, 2 January, 1953, p.10] and was featured prominently in a double page spread in The Illustrated London News ["A vision of the future: An airport for helicopters in the heart of London”, 2 February 1952, pp. 170-71].

13 “Festival air station”, Flight Magazine, 17 October 1952, pp. 504-05. The site of Dome of Discovery, adjacent to the County Hall building, was actually used as a temporary landing pad for trial helicopter services between Heathrow Airport and Waterloo in the 1955-56.

14 “Helicopters and the South Bank”, Flight Magazine, 23 October 1953, p. 573.

${ }^{15}$ Rowntree, D. 1961, “Alternative to chaos”, The Guardian, 7 January, p. 5. Glover’s scheme was featured in a contemporaneous Pathé News report titled "Market Report", viewable at $<$ www.britishpathe.com/video/market-report>. It was not built.

${ }^{16}$ In 1931 architect Charles Glover advanced a fanciful idea for a massive wheel shaped airport actually constructed over and above existing buildings in the Kings Cross area, cf. "London of the future: A central airport”, Illustrated London News, 6 June 1931, pp. 956-57; The Builder, 25 December 1931, p. 1046.

${ }^{17}$ Ministry of Aviation, Report of the Committee on the Planning of Helicopter Stations in the London Area (London: HMSO, 1961), p. 4.

${ }^{18}$ Called London Heliport, <http://www.londonheliport.co.uk/>.

19 'The commercial future of helicopters', Flight Magazine, 14 November 1952, p. 621.

${ }^{20}$ There is a Pathé News report on this start of this service, see <www.britishpathe.com/video/helicopterservice/query/Speke>.

21 “BEA helicopter passenger service”, Flight Magazine, 2 March 1950, p. 284.

22 "Passenger by helicopter”, The Times, 28 February 1950, p. 6. Davies quote taken from “Passenger helicopter service to begin in June”, Manchester Guardian, 28 February 1950. The service was also featured in a short news clip by British Pathé , 1950, <http://www.britishpathe.com/video/helicopterservice/>.

23 “The commercial future of helicopters", Flight Magazine, 14 November 1952, p. 620.

24 “Helicopter to Birmingham”, The Times, 21 May 1951, p. 4.

${ }^{25}$ Quote from a talk by Henry Hough at the Liverpool Luncheon Club, reported in "Liverpool prepares for helicopters”, Flight Magazine, 10 December 1954, p. 839.

${ }^{26}$ Through the first half of the twentieth century, up until the mid 1960s, the City Engineer was an influential role in local government with the post holder having a wide ranging remit for the planning, highways and daily management of towns and cities.

${ }^{27}$ Liverpool City Centre Plan (City and County Borough of Liverpool, 1965), p. 126.

${ }^{28}$ Quotation from “Liverpool prepares for helicopters”, Flight Magazine, 10 December 1954, p. 839.

${ }^{29}$ Ibid.

${ }^{30}$ His lecture was reproduced in H.T. Hough, "The design of helicopter operating sites for passenger services”, The Surveyor and Municipal and County Engineer, 24 December 1955, p. 1249-52. It was also reported at length in "Design of helicopter stations", Flight Magazine, 18 November 1995, p. 773-74.

31 “Design of helicopter stations”, Flight Magazine, 18 November 1995, p. 774. 
${ }^{32}$ Quotation from “Liverpool prepares for helicopters”, Flight Magazine, 10 December 1954, p. 839.

${ }^{33}$ A plan of this site is available from the Liverpool Record Office, ref. 352 ENG/2/15590.

${ }^{34}$ Although it seems that the Mersey Docks and Harbour Board were resistant, seeking to kept their land holdings for their own development schemes, cf. "Inter-city air services: Liverpool difficulty over central landing site”, The Surveyor and Municipal and County Engineer, 19 December 1959, p. 1066.

${ }^{35}$ See discussion in R. Brook and M. Dodge, Infra_MANC: Post-war Infrastructures of Manchester (Bauprint: Manchester, 2012).

${ }^{36}$ Hough quoted in "Inter-city air services: Liverpool difficulty over central landing site”, The Surveyor and Municipal and County Engineer, 19 December 1959, p. 1066.

${ }^{37}$ Amos, F.J.C. 1973, “Liverpool”, in Holliday, J. (ed.) City Centre Redevelopment (London: Charles Knight \& Co.), p. 180.

${ }^{38}$ See T. Hart, The Comprehensive Development Area (Edinburgh: Oliver \& Boyd, 1968) for a good explanation of the nuances and powers attached to the 1944 and 1947 Town and Country Planning Acts.

${ }^{39}$ Cf. P. Shapely, "The entrepreneurial city: the role of local government and city-centre redevelopment in post-war industrial English cities”, Twentieth Century British History, 22(4) (2011): 498-520.

${ }^{40}$ Liverpool City Centre Plan (City and County Borough of Liverpool, 1965), p. 125.

${ }^{41}$ Ibid. p. 48.

${ }^{42}$ F.J.C. Amos, Liverpool City Centre Plan Review 1970 (Liverpool City Planning Department, 1970).

${ }^{43}$ Mr John Profumo, Parliamentary Secretary to the Ministry of Civil Aviation, comments in the House of Commons debate on 'Helicopter station, London', 2 February 1953 [Hansard, HC Debate 2 February 1953 vol. 510 cc1615-26].

${ }^{44} \mathrm{~N}$. Borg, "Discussion on heliports in urban areas and structural tests on an experimental helicopter platform”, Institution of Civil Engineers Proceedings, 33(3) (1966): 364.

${ }^{45}$ The only notable exception was the extensive use of passenger helicopters in supplying the North Sea oil and gas industry.

${ }^{46}$ M.L. Clausen, The Pan Am Building and the Shattering of the Modernist Dream (MIT Press, Cambridge, MA, 2005) 